RASĀYAN J. Chem.

Vol. 13 | No. 1 |306 - 321| January - March | 2020 ISSN: 0974-1496 | e-ISSN: 0976-0083 | CODEN: RJCABP

\title{
PHYTOCHEMICAL GINKGOLIDE B PROTECTS CULTURED NEUROBLASTOMA SH-SY5Y CELLS AGAINST Aß(25-35) INDUCED OXIDATIVE STRESS RESPONSES BY MAINTAINING THE MITOCHONDRIAL INTEGRITY
}

\author{
Navrattan Kaur ${ }^{1}$, Sharanjot Kaur ${ }^{2}$, Meenu Saini ${ }^{1}$, Monisha Dhiman ${ }^{2}$ \\ and Anil K. Mantha ${ }^{1, *}$ \\ ${ }^{1}$ Department of Zoology, School of Basic and Applied Sciences, Central University of Punjab, \\ Bathinda, Punjab, India \\ ${ }^{2}$ Department of Microbiology, School of Basic and Applied Sciences, Central University of \\ Punjab, Bathinda, Punjab, India \\ *E-mail: anil.mantha@cup.edu.in
}

\begin{abstract}
Alzheimer's disease is associated with oxidative stress induced by accumulation of $A \beta$ peptide, by disrupting the mitochondrial function. In this study, the oxidative stress responses induced by $A \beta(25-35)$ and protective effects of diterpenoid phytochemical Ginkgolide B (GB) were evaluated by the determination of cellular oxidant/antioxidant status, oxidative DNA base damage and repair capacity of cells through evaluation of mitochondrial BER pathway status and the multifunctional enzyme APE1 in human neuroblastoma SH-SY5Y cells, and evaluation of mitochondrial membrane potential and changes in apoptotic pathway. It was found that $A \beta(25-35)$ treatment increased ROS/RNS production, increased the activities of antioxidant SOD and Catalase enzymes, decreased the expression of mitochondrial SOD (SOD2), induced oxidative DNA base damage, might be altered the repair capacity as analyzed by the transcriptional and translational expression of APE1 and other BER pathway enzymes in the mitochondria, disrupted the mitochondrial membrane potential and induced apoptosis as a result of these responses. Phytochemical modulation by the pre-treatment of GB for $3 \mathrm{hr}$ followed by the treatment of A $\beta(25-35)$ for a period of $24 \mathrm{hr}$ caused decrease in ROS/RNS, increase in activities of antioxidant enzymes and expression of SOD2, decreased oxidative DNA base damage and increased transcriptional and translational expression of APE1, increased/restored expression of APE1 and polymerase gamma $(\gamma)$ in the mitochondria, restored mitochondrial membrane potential and rescued the SH-SY5Y cells from mitochondrial-mediated apoptosis against A $\beta(25-35)$ induced oxidative stress responses. Taken together, GB showed neuroprotection by restoring cellular antioxidant defense system, repair capacity of cells and restoring mitochondrial integrity (genome and membrane potential), thus rescuing the SH-SY5Y cells from $\mathrm{A} \beta(25-35)$ induced oxidative stress responses.
\end{abstract}

Keywords: ROS/RNS, Oxidative Stress, Amyloid Beta, Ginkgolide B, Alzheimer's Disease, AP Endonuclease 1, BER-pathway

(C) RASĀYAN. All rights reserved

\section{INTRODUCTION}

Oxidative stress has been known to play a major role in aging and age-related neurodegenerative disorders like Alzheimer's disease (AD), the most common form of dementia. The major hallmark of $\mathrm{AD}$ is an accumulation of amyloid plaques that form via aggregation of amyloid-beta $(A \beta)$ protein which results from proteolytic processing of amyloid precursor protein (APP) by the action of $\beta$-secretase and $\gamma$ secretase enzymes involved in the amyloidogenic pathway. ${ }^{1}$ The mitochondrial functions are most affected by $\mathrm{A} \beta$, through disruption of mitochondrial biogenesis (fusion-fission imbalance) and function of electron transport chain (ETC) complexes, thus leading to exacerbation of oxidative stress and finally neurodegeneration. ${ }^{2-5}$

Rasayan J. Chem., 13(1), 306-321(2020)

http://dx.doi.org/10.31788/RJC.2020.1315596

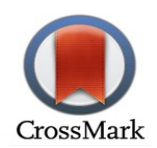


RASĀYAN J. Chem.

Vol. 13 | No. 1 |306 - 321| January - March | 2020

When reactive oxygen and reactive nitrogen species (ROS \& RNS) production exceeds cellular antioxidant defenses, oxidative damage occurs. This leads to the oxidation of proteins, lipids and nucleic acids. The cells possess a variety of intracellular antioxidants to combat the ROS-elicited oxidative stress. Superoxide dismutase (SOD), Catalase (CAT) and Glutathione peroxidase (GPx) are the prominent antioxidants present in the cytoplasm, nucleus and peroxisomes. The activities and expression of antioxidant enzymes are altered in $\mathrm{AD}$ brain ${ }^{6-8}$, therefore further affecting normal cellular functions.

Oxidative DNA base damage leads to oxidized base lesions that are repaired by the base excision repair (BER) pathway. This is a major repair pathway in the mitochondria for repairing oxidized base lesions. It consists of four major enzymes viz. a DNA glycosylase OGG1, Apurinic/Apyrimidinic Endonuclease 1 (APE1), DNA polymerase gamma $(\gamma)$ and DNA ligase III. ${ }^{9}$ Increased oxidative DNA base damage, as measured with 8-oxoguanine (8-oxoG), and reduced capacity of proteins responsible for removing of DNA damage, including OGG1, were detected in brains of AD patient. ${ }^{10} \mathrm{~A} \beta(1-42)$ showed a pronounced increase in 8-oxodG and AP sites in differentiated SH-SY5Y neuronal cells than in undifferentiated SHSY5Y cells. ${ }^{11}$ APE1, an important enzyme of BER pathway, is known to play a dual role, DNA repair and redox regulation. ${ }^{12-17} \mathrm{~A} \beta$ induced oxidative stress showed induction in APE1's interaction with neuronal proteins like pyruvate kinase muscle isoenzyme (PKM2) and tropomodulin 3 in PC12 and SH-SY5Y cells, suggesting that regulatory functions have a key role to play under $A \beta$ induced oxidative stress. ${ }^{18}$ APE1 has also been known to show neuroprotection against $A \beta(25-35)$ mediated oxidative stress in SHSY5Y cells; when complemented with phytochemical Ginkgolide B (GB), where GB showed enhanced neuroprotection through the improvement of mitochondrial oxidative phosphorylation. ${ }^{3}$ According to another study, pre-treatment of Curcumin enhanced expression of Nrf2 as well as DNA repair proteins, APE1, pol $\beta$ and PARP1, against A $\beta(25-35)$ induced oxidative stress in SH-SY5Y cells. ${ }^{19}$

Further, neurodegenerative diseases are associated with the loss of neurons because of oxidative stress. $\mathrm{A} \beta$ inhibits the activity of mitochondrial complexes, which results in decreased ATP production and increased ROS production. This affects the functioning of mitochondria and causes a decrease in mitochondrial membrane potential, which further causes the opening of mitochondrial permeability transition pores [MPTPs]. ${ }^{20}$ This results in the release of cytochrome $\mathrm{c}$ (cyt c) from the intermembrane space of mitochondria. Release of cyt c triggers the caspase cascade (caspase 9 and caspase 3 activation) and results in the formation of apoptosome. Apoptosis-inducing factor (AIF) is also released from the mitochondria which is a pro-apoptotic factor associated with late events in apoptosis. ${ }^{2}$ AIF is present in the intermembrane space of the mitochondrion as a $62 \mathrm{kDa}$ protein, where it regulates ROS production through oxidative phosphorylation via scavenging ROS. It is translocated into the cytoplasm (\& nucleus) upon membrane permeabilization as a cleaved (truncated) $57 \mathrm{kDa}$ protein. In the nucleus, it causes DNA fragmentation and apoptosis through caspase-independent manner. ${ }^{21,22}$

Several phytochemicals are being now studied for their roles in alleviating/managing CNS disorders. Among these, Ginkgolides (Table-1) are a class of phytochemicals obtained from a fossil tree, Ginkgo biloba. These are diterpenoids that were earlier found to possess antagonistic activity against plateletactivating factor and are now being investigated for its potential against various metabolic disorders. ${ }^{23} \mathrm{AD}$ is associated with oxidative stress and several antioxidant phytochemicals have been found to be scavenging oxidative free radicals ${ }^{24,25}$, therefore phytochemical GB was analyzed in the present study for its potential against $\mathrm{AD}$. The aim of the present study was to characterize the relationship between levels of oxidative stress, antioxidant status, BER-pathway enzymes expression, mitochondrial membrane potential and apoptosis under $A \beta$-induced oxidative stress and combination treatment of phytochemical Ginkgolide B, for determination of neuroprotective efficacy by modulating the strategies employed, in human neuroblastoma SH-SY5Y cells.

\section{EXPERIMENTAL}

\section{Materials}

The human neuroblastoma cell line SH-SY5Y was a generous gift from Dr. Tushar K. Maiti, Regional Centre for Biotechnology, India. Ginkgolide B was purchased from Sigma. BSA and Trypsin were obtained from HiMedia. Taq reaction mix was procured from Sigma. The cDNA synthesis kit was purchased from BioRad. Proteinase $\mathrm{K}$ was procured from Ambion. RNase A and Trizol were purchased from Invitrogen. $A \beta(25-35)$ peptide was purchased as $\geq 95 \%$ pure from GL Biochem (Shanghai Ltd.). 
RASĀYAN J. Chem.

Vol. 13 | No. 1 |306 - 321| January - March | 2020

DNase 1 and protease inhibitor cocktail were procured from Thermo Fisher Scientific. The antibody against 8-oxo-dG was obtained from Trevigen. 4',6-diamidino-2-phenylindole (DAPI) and Alexa Fluor 488 anti-mouse antibody were bought from Molecular Probes.

Table-1: Chemical Structures* of various ginkgolides from the plant Ginkgo biloba (*PubChem)

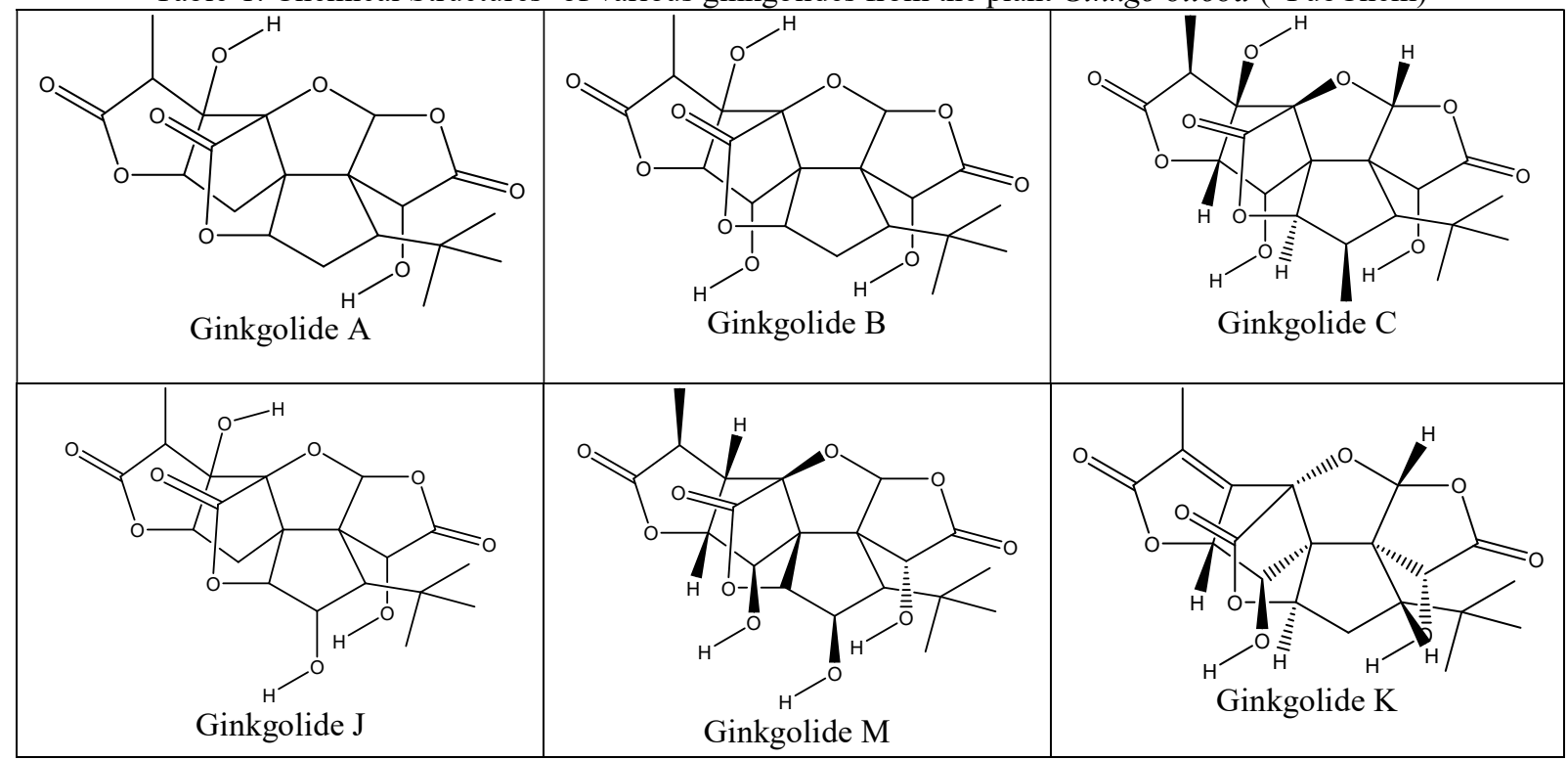

\section{Cell Culture and Treatments}

SH-SY5Y cells were grown in Dulbecco's Modified Eagle's Medium (DMEM; Gibco) supplemented with $10 \%$ fetal bovine serum (FBS) and 1\% Penicillin-Streptomycin. They were maintained in a humidified $5 \% \mathrm{CO}_{2}$ atmosphere at $37^{\circ} \mathrm{C}$. Before experiments, human neuroblastoma SH-SY5Y cells were harvested using trypsin, pelleted and resuspended in this medium. Then, these were seeded in 6-well plates, $60 \mathrm{~mm}$ dishes and $100 \mathrm{~mm}$ dishes at $80 \%$ confluence as required. For treatments, Ginkgolide B (GB) was dissolved in DMSO, while $\mathrm{A} \beta(25-35)$ peptide was dissolved in sterile double-distilled $\mathrm{H}_{2} \mathrm{O}$ and added directly to the media. $10 \mu \mathrm{M}$ was selected as the non-cytotoxic dose for both GB and A $\beta(25-35)$. Thus, cells were pre-treated with GB for $3 \mathrm{hr}$ and subsequently exposed to $A \beta(25-35)$ for $24 \mathrm{hr}$ and with GB and $A \beta(25-35)$ alone for $24 \mathrm{hr}^{3,18}$

\section{ROS Measurement}

Human neuroblastoma SH-SY5Y cells were seeded in 6 well plates at the density of $3 \times 10^{5}$ cells per well. After $24 \mathrm{hr}$, treatment was given in four groups as stated above. After $24 \mathrm{hr}$, cells were washed with PBS and trypsinized. After trypsinization, the SH-SY5Y cells $\left(1 \times 10^{5}\right)$ were added to the working solution of $\mathrm{H}_{2}$ DCFDA (Invitrogen), $2 \mu \mathrm{M}$, and incubated at $37^{\circ} \mathrm{C}$ for $30 \mathrm{~min}$. After incubation, cells were centrifuged at $130 \mathrm{~g}$ for $5 \mathrm{~min}$ and washed with PBS and then suspended in PBS and the sample was run on flow cytometry, $\mathrm{C} 6$ accuri (BD Biosciences) along with an unstained control (without $\mathrm{H}_{2} \mathrm{DCFDA}$ ) sample using $488 \mathrm{~nm}$ laser for excitation and detected at $535 \mathrm{~nm}$ (FL1) ${ }^{26}$ The data were analyzed using C6 accuri flow cytometer software (BD Bioscience).

\section{RNS Measurement}

SH-SY5Y cells were seeded in 96-well $\left(1 \times 10^{5}\right)$ plates as well as on coverslips in 6-well plates $\left(3 \times 10^{5}\right)$. After $24 \mathrm{hr}$ cells were treated in four groups as stated above for $24 \mathrm{hr}$, followed by washing with PBS and incubation in the dark for 30 min with $2 \mu \mathrm{M}$ of DAF-FM (Invitrogen) [Ex 478nm /Em 515nm]. After washing twice with PBS the SH-SY5Y cells were incubated for $30 \mathrm{~min}$, fluorescence was recorded and intracellular ROS fluorescence was captured at the excitation wavelength of $478 \mathrm{~nm}$ and an emission wavelength of $515 \mathrm{~nm}$ using BioTek Multiplate Reader and through Confocal Laser Scanning Microscope (Olympus FV 1200), respectively., ${ }^{3,27}$ 
RASĀYAN J. Chem.

Vol. 13 | No. 1 |306 - 321| January - March | 2020

Immunodetection of 8-oxo-dG DNA Base Damage Sites

SH-SY5Y cells were seeded at a density of $2 \times 10^{5}$ cells in 6-well plates containing glass coverslips precoated with poly-L-lysine. Following the treatment, SH-SY5Y cells were fixed with chilled methanol and acetone for $15 \mathrm{~min}$ each. After fixation, cells were treated with $0.05 \mathrm{~N} \mathrm{HCl}$ for $5 \mathrm{~min}$ on ice, followed by incubation with $100 \mu \mathrm{g} / \mathrm{ml}$ RNase in $150 \mathrm{mM} \mathrm{NaCl}, 15 \mathrm{mM}$ sodium citrate for $1 \mathrm{hr}$ at $37^{\circ} \mathrm{C}$. Next, DNA was denatured in situ with $0.15 \mathrm{~N} \mathrm{NaOH}$ for $4 \mathrm{~min}$ and stained with $0.2 \mu \mathrm{g} / \mathrm{ml}$ Hoeschst 33342 for $10 \mathrm{~min}$. Subsequently, cells were incubated with $5 \mu \mathrm{g} / \mathrm{ml}$ proteinase $\mathrm{K}$ in $20 \mathrm{mM}$ Tris, $1 \mathrm{mM}$ EDTA (pH 7.5) for 10 min at $37^{\circ} \mathrm{C}$, blocked with $5 \% \mathrm{FBS}$ for $1 \mathrm{hr}$ at $37^{\circ} \mathrm{C}$ and incubated with anti-8-hydroxyguanine antibody $(1: 250)$ at $4^{\circ} \mathrm{C}$ overnight in a humidified chamber. Lastly, cells were incubated with anti-mouse IgG (Alexa Fluor 488) for $1 \mathrm{hr}$ in dark at $37^{\circ} \mathrm{C}$ and mounted with mounting media. ${ }^{28}$ The fluorescence was captured using 60X oil objective confocal laser scanning microscope (Olympus FV1200). The images were processed with the aid of FV10-ASW 4.2 software (Olympus).

\section{Isolation of Mitochondria and Preparation of Lysates}

SH-SY5Y cells trypsinized following treatment in four groups and pelleted down by centrifugation at $2000 \mathrm{rpm}$ for $5 \mathrm{~min}$ at $4^{\circ} \mathrm{C}$. The cell pellet was washed with PBS and then incubated for $30 \mathrm{~min}$ in icecold buffer $\left[75 \mathrm{mM} \mathrm{NaCl}, 1 \mathrm{mM} \mathrm{NaH} \mathrm{PO}_{4}, 8 \mathrm{mM} \mathrm{Na}_{2} \mathrm{HPO}_{4}, 250 \mathrm{mM}\right.$ sucrose, $0.05 \%$ digitonine and Halt protease inhibitor cocktail (Thermo Scientific)] by vortexing after every $5 \mathrm{~min}$. The cell suspension was then centrifuged at $800 \mathrm{~g}$ for $10 \mathrm{~min}$ at $4^{\circ} \mathrm{C}$. The supernatant was then taken and centrifuged at $20,000 \mathrm{~g}$ for $15 \mathrm{~min}$ at $4^{\circ} \mathrm{C}$. The pellet was then washed with wash buffer [20mM HEPES (pH-7.4), $250 \mathrm{mM}$ Sucrose, $1 \mathrm{mM}$ DTT] at $8000 \mathrm{~g}$ for $5 \mathrm{~min}$. The pellet was then suspended in lysis buffer [20mM HEPES (pH 7.4), 1mM EDTA, $1 \mathrm{mM}$ DTT, $300 \mathrm{mM} \mathrm{KCl,} 5 \%$ glycerol, $0.5 \%$ Triton X-100 and Halt protease inhibitor cocktail] according to the protocol described. ${ }^{3,29}$ The amount of protein was determined using Bradford's reagent.

\section{Preparation of Total Cell Lysates}

Whole-cell extracts from the SH-SY5Y cells were prepared in lysis buffer [20mM Tris-Cl $(\mathrm{pH}-7.5)$, $150 \mathrm{mM} \mathrm{NaCl}, 1 \mathrm{mM}$ EDTA, $0.1 \%$ NP-40 and protease inhibitor cocktail] and left on ice for 30 min with vortexing every $10 \mathrm{~min}$. After vortexing, lysates were clarified by centrifugation at $20,000 \mathrm{~g}$ for $20 \mathrm{~min}$ at $4^{\circ} \mathrm{C}$ and stored at $-20^{\circ} \mathrm{C}$ until use. Bradford assay was carried out for determining the concentration of protein in each sample. ${ }^{3,18}$

\section{SOD Activity Assay}

SOD activity was performed as described previously in both mitochondrial and whole-cell lysates. ${ }^{13,30}$ The final assay mixture contained $0.1 \mathrm{mM}$ sodium phosphate buffer $(\mathrm{pH} 8), 3 \mathrm{mM}$ EDTA, and $8.1 \mathrm{mM}$ pyrogallol and $20 \mu \mathrm{g}$ of the protein sample. Change in absorbance was measured at $0 \mathrm{~min}, 1 \mathrm{~min}$ and 3 min at $420 \mathrm{~nm}$ using a spectrophotometer (Shimadzu). The enzyme activity was expressed as U/mg of protein. One unit of SOD activity defined as the amount of enzyme that causes half-maximal inhibition of auto-oxidation of pyrogallol. The following formula was used for calculating the SOD activity:

$$
\text { SOD Activity }=\frac{[(\Delta \text { OD Reference }-\Delta \text { OD Sample }) \times \text { Total Volume }]}{(\underline{\Delta \text { OD Reference })} \times \text { Sample Volume }}
$$

\section{In-Gel Catalase Activity Assay}

The in-gel assay for catalase activity was performed as described previously. ${ }^{30,31} 100 \mu \mathrm{g}$ of protein was resolved in $8 \%$ native PAGE using electrophoresis buffer $\left(200 \mathrm{mM}\right.$ glycine, $25 \mathrm{mM}$ Tris-Cl) at $4{ }^{\circ} \mathrm{C}$, followed by rinsing in deionized $\mathrm{H}_{2} \mathrm{O}$ for $10 \mathrm{~min}$. Then, these gels were incubated in $0.003 \%$ of $\mathrm{H}_{2} \mathrm{O}_{2}$ for 10 min followed by washing twice with distilled $\mathrm{H}_{2} \mathrm{O}$. Next, the gels were incubated in a solution of $2 \%$ ferric chloride and $2 \%$ potassium ferricyanide until dark bands appeared and were then washed with $\mathrm{H}_{2} \mathrm{O}$ extensively. Then the images were captured using GelDoc imaging system (ProteinSimple).

\section{Western Blot Analysis}

$60 \mu \mathrm{g}$ of total protein from each sample made from different treatment groups of SH-SY5Y cells was taken, mixed with SDS loading buffer and loaded in 10\% SDS-polyacrylamide gel and electrophoresis 
RASĀYAN J. Chem.

Vol. 13 | No. 1 |306 - 321| January - March | 2020

was performed. In the case of mitochondrial lysates, gradient gel (8-15\%) was prepared and run at $100 \mathrm{~V}$. After the dye came out of the gel, the gel was removed and placed in the cassette for transfer of proteins on the nitrocellulose (NC) membrane in the transfer buffer overnight at $30 \mathrm{~V}$. The membrane was then washed with PBST (PBS containing $0.1 \%$ tween-20) and blocked in blocking buffer (5\% non-fat dry milk in PBST) for $2 \mathrm{hr}$ and washed again with PBST and then probed with either anti-APE1 rabbit polyclonal (in-house generated, gift from Prof. Sankar Mitra, University of Texas Medical Branch, Galveston, USA) or mouse monoclonal (DSHB) antibody, OGG1 mouse monoclonal antibody (DSHB), DNA pol $\gamma$ rabbit polyclonal antibody (Invitrogen), SOD2 rabbit polyclonal antibody, AIF (E-1, sc13116) mouse monoclonal and Caspase 9 p35 rabbit polyclonal (SantaCruz Biotechnology) with 1:500 to 1: 1000 dilution in blocking buffer for overnight at $4{ }^{\circ} \mathrm{C}$. The membrane was again washed with PBS and incubated in an anti-mouse IgG/ anti-rabbit IgG secondary antibody (Genei) (1:5000) for $1 \mathrm{hr}$ and then washed again with PBST thrice and imaging was done using ChemiDoc Imaging System [ProteinSimple or BioRad]. ${ }^{19}$

\section{Semi-Quantitative RT-PCR}

Total RNA was extracted from the SH-SY5Y cells seeded in a 6-well plate at a density of $1 \times 10^{5}$ cells using the Trizol reagent (Invitrogen) according to the manufacturer's recommendations. Next, DNase1 treatment was given to prepare DNA-free RNA prior to RT-PCR. $2 \mu \mathrm{g}$ of total RNA was used in each of these reactions according to the manufacturer's protocol (Thermo Fisher Scientific). The DNase1 treated RNA was reverse transcribed to cDNA using cDNA synthesis kit (BioRad). Primers used for RT-PCR reaction are as follows: APE1-forward: 5'-tggaatgtggatgggcttcgagcc-3' and reverse: 5'aaggagctgaccagtattgatga-3'; and $\beta$-actin-forward: 5'-ctaagtcatagtccgcctagaagca-3' and reverse: 5'tggcacccagcacaatgaa-3'. The cycling conditions used for the various primer sets are as follows: For APE1: $95^{\circ} \mathrm{C}$ for $5 \mathrm{~min}$, followed by 37 cycles of $95^{\circ} \mathrm{C}$ for $1 \mathrm{~min}, 58^{\circ} \mathrm{C}$ for $30 \mathrm{sec}, 60^{\circ} \mathrm{C}$ for $30 \mathrm{sec}, 72^{\circ} \mathrm{C}$ for $30 \mathrm{sec}$, and a final extension of $72^{\circ} \mathrm{C}$ for $7 \mathrm{~min}$. For $\beta$-actin, the reaction conditions were the same except for the annealing temperature of $60^{\circ} \mathrm{C}$ and $55^{\circ} \mathrm{C}$. PCR products were analyzed by electrophoresis on $2 \%$ agarose gel. The bands were imaged with GelDoc image-analyzer (BioRad). ${ }^{19}$

\section{Immunoflourescence and Confocal Laser Scanning Microscopy (CLSM)}

The localized subcellular distribution/expression of APE1 was evaluated by immunoflourescence using CLSM (Olympus FV1200). SH-SY5Y cells were seeded on glass coverslips placed in 6-well plates and after $70 \%$ confluence, they were treated in four groups: Control, $10 \mu \mathrm{M} \mathrm{GB}, 10 \mu \mathrm{M} \mathrm{A} \beta(25-35)$ and pretreatment of $10 \mu \mathrm{M}$ GB for $3 \mathrm{hr}$, followed by oxidative stress induction by $\mathrm{A} \beta(25-35)$ for $24 \mathrm{hr}$ as described above. The SH-SY5Y cells were then washed with 1X PBS and one set was incubated with mitotracker (Invitrogen) at a concentration of $200 \mathrm{nM}$ for $1 \mathrm{hr}$ and then fixed with $3 \%$ paraformaldehyde, PFA (another set was fixed without mitotracker incubation) in PBS for $10 \mathrm{~min}$ at $37^{\circ} \mathrm{C}$, followed by washing with PBS and permeabilization with $0.1 \%$ Triton X in PBS for $3 \mathrm{~min}$. Then these cells were again washed with PBS and blocked with the blocking buffer (10\% FBS in PBS) for $30 \mathrm{~min}$, followed by washing with PBS and incubation in primary mouse anti-APE1 monoclonal antibody $(1: 100)$ in antibody solution $\left(0.1 \%\right.$ Triton $\mathrm{X}$ and $1 \%$ FBS in PBS) overnight at $4^{\circ} \mathrm{C}$. Then the SH-SY5Y cells were washed with PBS thrice, and incubated with Alexa-Flour 488 anti-mouse secondary antibody (Invitrogen, 1:400) in antibody solution for $90 \mathrm{~min}$, followed by washing with PBS and staining with DAPI for nuclear staining for $15 \mathrm{~min}$. The coverslips were then mounted on glass slides using PBS and images were captured using CLSM. ${ }^{19}$

\section{JC-1 Assay}

JC-1 $\left(5,5^{\prime}, 6,6^{\prime}\right.$-tetrachloro-1,1',3,3'-tetraethylbenzimidazolylcarbocyanine iodide) is normally a green fluorescent dye that forms red J-aggregates in mitochondria in response to higher membrane potential and therefore the ratio of red/green fluorescent intensity enables distinguishing healthy/energized mitochondria that may increase or decrease in response to the treatment. For this, cells were seeded overnight in 6-well plates at a density of $1 \times 10^{5} \mathrm{SH}-\mathrm{SY} 5 \mathrm{Y}$ cells/well and given appropriate treatments. Cells were then trypsinized and pelleted down by centrifugation at 2000rpm. Then, the SH-SY5Y cells 
RASĀYAN J. Chem.

Vol. 13 | No. 1 |306 - 321| January - March | 2020

were equilibrated in PBS and pelleted down. Re-suspended cells were incubated with $50 \mu \mathrm{M}$ JC-1 [Invitrogen] $(5 \mu \mathrm{g} / \mathrm{ml})$ for $15 \mathrm{~min}$ at $37^{\circ} \mathrm{C}$ according to the manufacturer's protocol. After washing with PBS twice, finally, re-suspended them in $100 \mu 1$ of PBS. Fluorescence intensity was then read at the excitation wavelength of $515 \mathrm{~nm}$ and emission wavelength $529 \mathrm{~nm}$ using C6 accuri flow cytometer (BD Biosciences) as per the protocol described. ${ }^{32}$

\section{Densitometric and Statistical Analysis}

Densitometric measurements of the RT-PCR and Western blot were performed by using ImageLab software (BioRad). Quantifications of the PCR product levels and Western blot protein bands were estimated by comparing the intensity of the specific band from the treatment sample to those from the control. The experimental data were normalized using $\beta$-actin and Cox-IV as an internal standard for total cell lysates and mitochondrial lysates, respectively. Data are presented as mean \pm standard deviation and mean \pm standard error for the treatment groups. The statistical differences were determined using a paired student's t-test between the control and experimental samples.

\section{GB Alleviates A $\beta$ (25-35)-induced ROS/RNS Burden}

\section{RESULTS AND DISCUSSION}

At first SH-SY5Y cells were treated with non-cytotoxic doses of $10 \mu \mathrm{M} \mathrm{GB}, 10 \mu \mathrm{M} A \beta(25-35)$, and pretreatment of $10 \mu \mathrm{M}$ GB for $3 \mathrm{hr}$ and followed by oxidative stress induction by $10 \mu \mathrm{M} \mathrm{A} \beta(25-35)$ for $24 \mathrm{hr}$ time period. Flowcytometric determination using H2DCFDA dye after $24 \mathrm{hr}$ time period showed that the production of ROS levels decreased by $40 \%$ and increased by $20 \%$ in GB and $\mathrm{A} \beta(25-35)$ treated SHSY5Y cells, respectively, as compared to the untreated control SH-SY5Y cells. Whereas, pre-treatment of GB followed by oxidative stress induction by $A \beta(25-35)$ showed a decrease in ROS production by $39 \%$ as compared to $\mathrm{A} \beta(25-35)$ treated $\mathrm{SH}-\mathrm{SY} 5 \mathrm{Y}$ cells (Fig.-1c).

We also examined the effect of $A \beta(25-35)$-elicited oxidative stress and the resultant effect on RNS levels by DAF-FM using both spectroscopic and microscopic determination. Treatment with GB for $24 \mathrm{hr}$ caused a reduction in RNS levels to a significant level as compared to the untreated control SH-SY5Y cells. However, exposure to $A \beta(25-35)$ resulted a significant increase in RNS levels when compared to untreated control SH-SY5Y cells. On the other hand, the pre-incubation of cells with GB for $3 \mathrm{hr}$ resulted in a significant attenuation of RNS levels as compared to A $\beta(25-35)$-stressed SH-SY5Y cells. A similar pattern of RNS levels was observed in both spectroscopic and confocal laser scanning microscope analysis after $24 \mathrm{hr}$ of the treatment period (Fig.-1a and $1 \mathrm{~b}$ ).

These results underline the mechanisms to a certain level strengthening for the role of $A \beta(25-35)$ in inducing oxidative stress. Our previous study also pointed out the toxic effects of $A \beta(25-35)$ on SHSY5Y and IMR-32 cells by decreasing cell viability. ${ }^{3}$ Earlier it was shown that $A \beta(25-35)$ is soluble in water and tends to form oligomers and treatment of $A \beta(25-35)$ caused degeneration of hippocampal neuron cultures. ${ }^{33}$ In line with our results, another study documented the protective effects of GB by increasing cell viability against glutamate-induced toxicity in hippocampal neurons. ${ }^{34}$ Recently a study on GB showed neuroprotection against oxygen-glucose deprivation-induced injury in rat endothelialastrocyte-neuron co-culture model. ${ }^{35}$

\section{GB Maintains Cellular Antioxidant Status Against A $\beta(25-35)$ Induced Oxidative Stress}

Further, we assessed the activity of the major intracellular antioxidant enzyme superoxide dismutase (SOD) in the presence of oxidative stress induced by $\mathrm{A} \beta(25-35)$ and pre-treatment with $\mathrm{GB}$. This antioxidant is responsible for converting superoxide radicals into hydrogen peroxide $\left(\mathrm{H}_{2} \mathrm{O}_{2}\right)$ and oxygen $\left(\mathrm{O}_{2}\right)$. The treatment of GB and $\mathrm{A} \beta(25-35)$ led to $12 \%$ and $18 \%$ increase in SOD activity, respectively, as compared to the untreated control SH-SY5Y cells. Furthermore, pre-treatment of these cells with GB before the addition of $A \beta(25-35)$ resulted in significant increase of $23 \%$ in SOD activity as compared to the untreated control SH-SY5Y cells, and a marginal increase by $4 \%$ as compared to $A \beta(25-35)$ treatment alone after $24 \mathrm{hr}$ of treatment period (Fig.-2a). In the case of Mn-SOD activity (Fig.-2b), which was analyzed in mitochondrial lysates, GB, $A \beta(25-35)$ and $\mathrm{GB}+\mathrm{A} \beta(25-35)$ treatments showed $45 \%, 43 \%$ and $56 \%$ increase in Mn-SOD activity as compared to the control SH-SY5Y cells. As compared to A $\beta(25-35)$ 
RASĀYAN J. Chem.

Vol. 13 | No. 1 |306 - 321| January - March | 2020

treatment, GB+A $\beta(25-35)$ showed an increase in Mn-SOD activity by $9 \%$ after $24 \mathrm{hr}$ of the treatment period. Along with this the protein expression of Mn-SOD was also evaluated in the mitochondrial lysates (Fig.-2c) and it was found that upon individual GB and $A \beta(25-35)$ treatments showed $44 \%$ decrease and $13 \%$ increase in SOD2 expression as compared to the control SH-SY5Y cells, respectively. Whereas GB pre-treatment and then $A \beta(25-35)$ treatment showed 33\% increase in SOD2 expression as compared to the $\mathrm{A} \beta(25-35)$ treatment alone in SH-SY5Y cells after $24 \mathrm{hr}$ of time point.

(a)

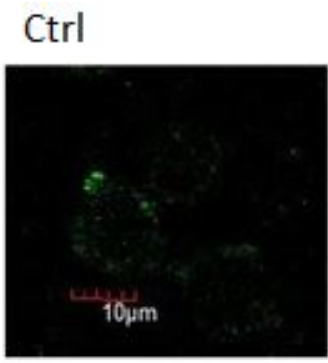

GB

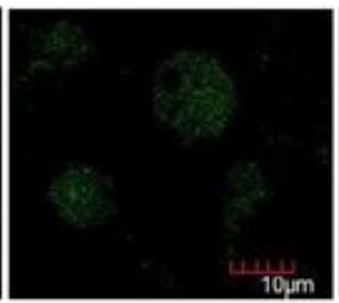

(b)

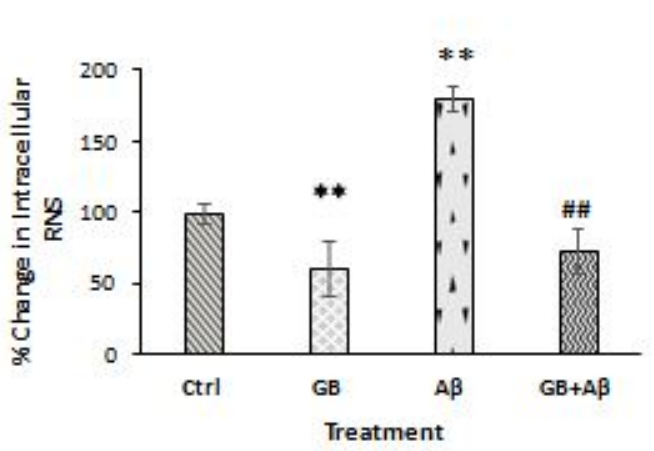

$A \beta$

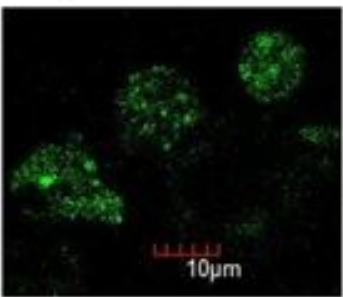

Ctrl

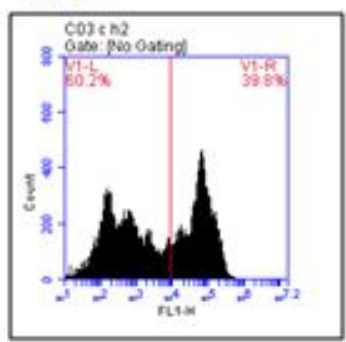

$A \beta$

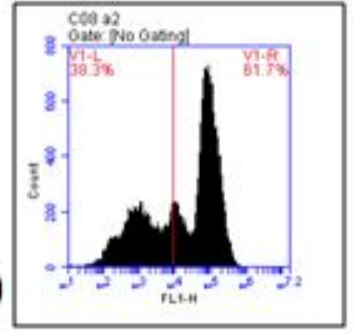

\section{$\mathrm{GB}+\mathrm{A} \beta$}

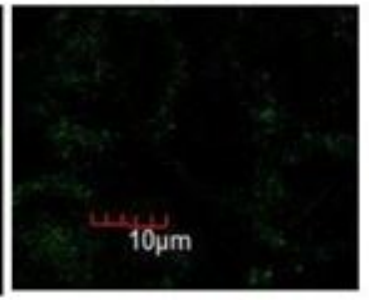

GB

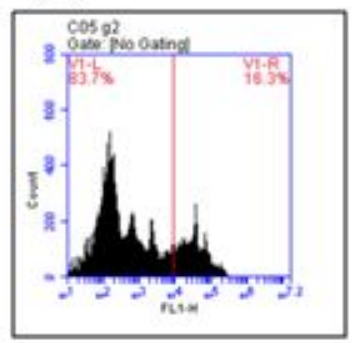

$\mathrm{GB}+\mathrm{A} \beta$

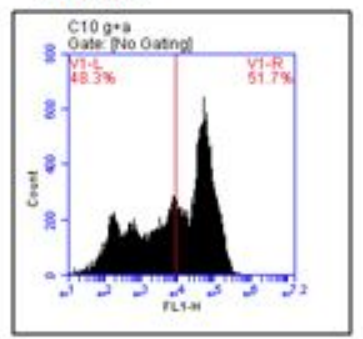

Fig.-1: Determination of intracellular RNS and ROS by DAF-FM and H2DCF-DA respectively upon treatment of GB, $A \beta(25-35)$, and pre-treatment with GB for $3 \mathrm{hr}$ followed by oxidative stress elicited by the treatment of $A \beta(25-$ 35) to SH-SY5Y cells. (a) Image of SH-SY5Y cells representing fluorescence as indicated by DAF-FM, that detects intracellular RNS, using confocal imaging, and (b) Graph representing \% change in RNS levels relative to control as

determined by DAF-FM using spectrophotometer. Results are presented as mean $\pm \mathrm{SD}$. Student's t-test was performed to analyze the results wherein ** represents $\mathrm{P}>0.001$ where GB and $\mathrm{A} \beta(25-35)$ were compared with untreated control; and $^{\# \#} \mathrm{P}>0.001$ represents $\mathrm{GB}+\mathrm{A} \beta(25-35)$ when compared with $\mathrm{A} \beta(25-35)(25-35)$ treatment. (c) Flow cytometric data showing fluorescence intensity versus count (number of cells) as determined by H2DCF-DA, that detects intracellular ROS.

This suggests that the increase in SOD activity upon $A \beta(25-35)$ treatment may be as a result of stimulation of SOD expression under A $\beta$ stress as illustrated by the Western blot analysis, whereas GB showed reduction in MnSOD expression, but increase in its activity, thus indicating its antioxidant potential in protecting the enzymatic activity of SOD. In case of $\mathrm{GB}+\mathrm{A} \beta(25-35)$ treatment, SOD expression and activity was found to be increased as compared to $A \beta(25-35)$ treatment alone, indicating that in the presence of $A \beta(25-35)$ stress the expression found to be stimulated and the activity of SOD was also increased further, this might be due to the antioxidant nature and protection by the phytochemical GB. 
RASĀYAN J. Chem.

Vol. 13 | No. 1 |306 - 321| January - March | 2020

In addition to SOD activity and expression, we also evaluated the activity of another important intracellular antioxidant i.e. Catalase. $\mathrm{H}_{2} \mathrm{O}_{2}$ generated by the action of SOD, is converted into $\mathrm{H}_{2} \mathrm{O}$ and $\mathrm{O}_{2}$ by the action of Catalase. The activity was calculated by an in-gel enzymatic assay and densitometric analysis was performed (Fig.-2d). Treatment with GB and $A \beta(25-35)$ led to an increase in Catalase activity by $13 \%$ and $19 \%$, respectively. When compared with the A $\beta(25-35)$-stressed SH-SY5Y cells, an increase in the activity of Catalase by $32 \%$ was found in cells pre-incubated with GB prior to the treatment of $\mathrm{A} \beta(25-35)$ peptide after $24 \mathrm{hr}$ time point.
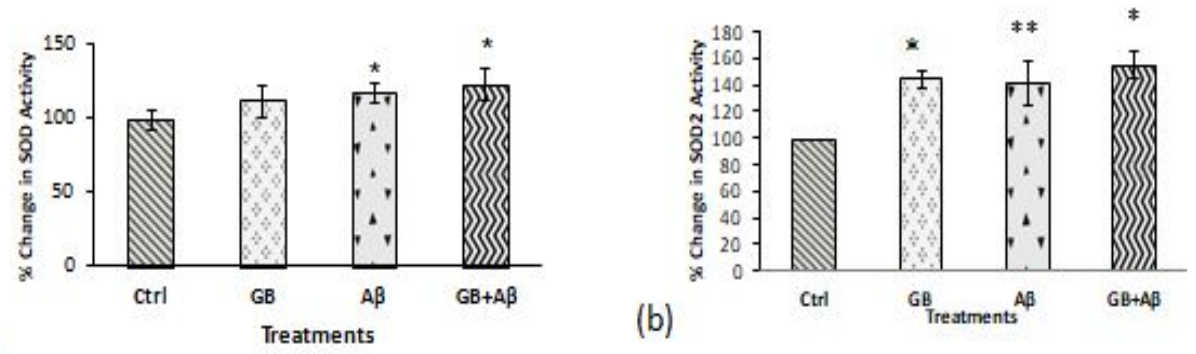

(a)
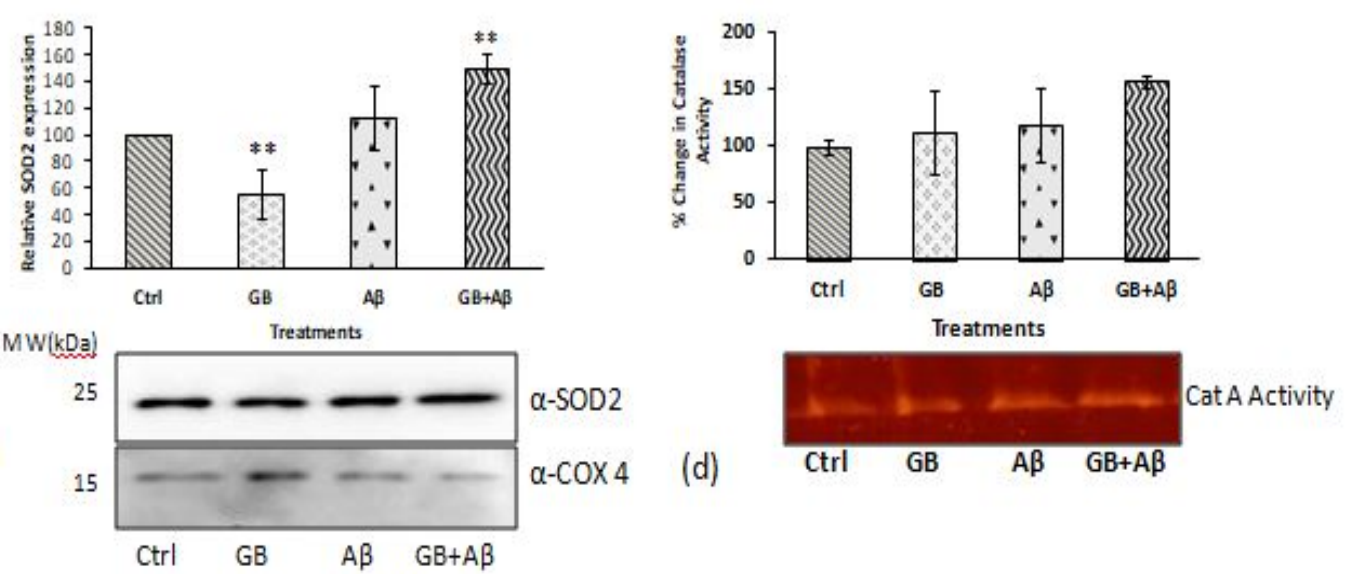

Fig.-2: Activities and Expression of Antioxidant Enzymes. (a) \% Change in total SOD activity relative to control in whole-cell extracts of SH-SY5Y cells treated in four groups. The data were considered statistically significant at ${ }^{*} \mathrm{p} \leq 0.05$ when $\mathrm{A} \beta(25-35)$ treated and $\mathrm{GB}+\mathrm{A} \beta(25-35)$ treated $\mathrm{SH}-\mathrm{SY} 5 \mathrm{Y}$ cells were compared with the untreated control. The results are presented as mean \pm standard deviation $(n=3)$. (b) \% Change in Mn-SOD (SOD2) activity in mitochondrial lysates of SH-SY5Y cells treated in four groups. The data were considered statistically significant at ${ }^{*} \mathrm{p} \leq 0.05$ and ${ }^{*} \mathrm{p} \leq 0.005$ when GB, A $\beta(25-35)$ treated and GB $+\mathrm{A} \beta(25-35)$ treated SH-SY5Y cells were compared with the untreated control. The results are presented as mean \pm standard deviation $(n=3)$. (c) \% Change in SOD2

(Mn-SOD) expression in mitochondrial lysates of SH-SY5Y cells treated in four groups as determined by Western blotting. COX-4 was used as a loading control for mitochondrial lysates. The data were considered statistically significant at ${ }^{* *} \mathrm{p} \leq 0.005$ when GB, A $\beta(25-35)$ treated, and GB $+\mathrm{A} \beta(25-35)$ treated SH-SY5Y cells were compared with control. The results are presented as mean \pm standard deviation $(n=3)$. (d) \% change in Catalase activity in whole-cell extracts of SH-SY5Y cells with different treatments as determined by in-gel activity assay. The results are presented as mean \pm standard error $(n=2)$.

These results advocate that the expression of antioxidant enzymes increase under the A $\beta$-stress but their activities do not increase proportionally, this might be due to protein oxidation caused by oxidative stress. Whereas SH-SY5Y cells pre-treated with antioxidant GB followed by $\mathrm{A} \beta(25-35)$ treatment are able to protect the functions of antioxidant enzymes by counteracting the $A \beta$-induced oxidative stress. In line with this, a study on AD brain samples showed increased expression of antioxidant enzymes (SOD, Catalase \& GSH-Px) as compared to age-matched control samples, whereas the activities of these enzymes showed a significant decrease in AD brain samples as compared to age-matched controls ${ }^{6}$. In our study, although the decrease in activity was not observed in the case of $A \beta(25-35)$ treatment, the increase in activity was not as proportional to the expression as it was observed in GB treatment alone, where a 
RASĀYAN J. Chem.

Vol. 13 | No. 1 |306 - 321| January - March | 2020

decrease in expression also showed an increase in activity. The decrease in activity is anticipated in prolonged exposure and/or increase in the concentration of A $\beta$ treatment to the SH-SY5Y cells. In addition, SOD activity was found to be decreased in SH-SY5Y cells upon A $\beta(1-42)$ treatment, whereas antioxidant GB's pre-treatment and then $A \beta(1-42)$ treatment showed restoration of SOD activity. ${ }^{11}$

\section{Analysis of 8-oxo-dG Sites: An Indicator of Oxidative DNA Base Damage}

The effect of ROS/RNS overproduction further disrupts the cellular biomolecules including the genetic material DNA. Oxidative damage to nucleic acids induce the production of base damage 8-oxo-dG sites, whose occurrence within the cell was studied and visualized by Confocal laser scanning microscopy. The results show that the exposure to $\mathrm{A} \beta(25-35)$ increases the production of 8-oxo-dG in SH-SY5Y cells. This may be due to the increase in oxidative stress upon $A \beta(25-35)$ treatment, a known oxidant and endogenous neurodegenerative agent. Apart from its localization in the nucleus, this oxidative marker is seen to be more pronounced in mitochondria. However, treatment with GB significantly lessened the generation of 8-oxo-dG sites in the mitochondria. The combination treatment of GB and A $\beta(25-35)$ showed a significant reduction in the generation of 8-oxo-dG sites in mitochondria when compared with A $\beta(25-35)$-stressed SH-SY5Y cells after $24 \mathrm{hr}$ of the time course (Fig.-3).

This point out towards the oxidative damage caused by $A \beta(25-35)$ to the mitochondrial genome may have adverse effects during $A D$. In line with this, the previous study showed that $A \beta(1-42)$ treatment resulted in increase in oxidative DNA damage estimated both by AP sites and 8-oxo-dG sites in total genome DNA and total RNA, respectively; and GB pre-treatment showed decrease in oxidative DNA damage against A $\beta$-induced oxidative stress as analyzed in undifferentiated and differentiated SH-SY 5Y cells. ${ }^{11}$ In line with these observations documented, another study showed AD mouse model with an increase in PARP1 expression, pointing out that AD pathology increases oxidative DNA damage ${ }^{36}$ and thus influencing/challenging the BER-pathway.

\section{Expression Analysis of BER Pathway Enzymes in the Mitochondria}

The expression of BER pathway enzymes was further evaluated in the mitochondria (Fig.-4a), the DNA glycosylase OGG1 expression was found to be modulated by $7 \%$ decrease and by $52 \%$ increase in GB treated and $A \beta(25-35)$ treated SH-SY $5 Y$ cells, respectively. On the other hand, GB+A $\beta(25-35)$ treatment showed 55\% decrease in OGG1 expression as compared to $A \beta(25-35)$ treatment alone (Fig.-4b). OGG1 initiates BER pathway by binding to 8-oxoG sites. Apart from repair activity, OGG1 has been known to be associated with the induction of inflammation. According to a study, OGG1 depletion resulted in a decrease in inflammation induced by TNF- $\alpha$ in mouse lungs and the interaction of OGG1 with transcription factors such as NF-kB/Rel A and RNAp-polII. ${ }^{37}$ Therefore, OGG1 may be playing other roles under $\mathrm{A} \beta$ stress in the mitochondria in $\mathrm{AD}$, which needs further investigation.

Next, the multifunctional enzyme APE1 expression was evaluated in the SH-SY5Y cells treated with GB and $\mathrm{A} \beta(25-35)$ alone showed $37 \%$ and $8 \%$ decrease in APE1 expression as compared to control SHSY5Y cells, respectively. The treatment of GB $+A \beta(25-35)$ showed $39 \%$ increase in the expression of APE1 as compared to A $\beta(25-35)$ treatment in SH-SY5Y cells (Fig.4c). GB-mediated marginal decrease in APE1's expression suggests that under the intervention of antioxidant treatment, the neuronal cells are not stimulated to increase the APE1 expression. The expression of APE1 increased by A $\beta(25-35)$ treatment as compared to GB alone, but decreased as compared to the control SH-SY5Y cells, pointing towards the inability of cells under A $\beta$ stress to maintain APE1 levels. The localization of APE1 expression in the mitochondria was confirmed by using mitotracker dye and visualized by Confocal imaging (Fig.-4e). Several studies have pointed out the impaired BER pathway in AD. ${ }^{38,39}$

Transcriptional and translational APE1 expression was found to be significantly lower in cortex of AD brains as compared to the healthy controls. ${ }^{39}$ In addition, OGG1 repair activity (AP lyase activity) was found to be increased with the addition of APE1 ${ }^{40}$ Therefore, the coordinated interaction is essential for repair activity of OGG1. ${ }^{41}$ In this study, GB+A $\beta(25-35)$ treatment caused increase in APE1 expression as compared to $A \beta(25-35)$ treated cells, thus pointing towards the role of increase in APE1's expression ascertained for the direct influence on the repair activity and thus BER pathway. 
RASĀYAN J. Chem.

This was followed by the expression analysis of gap-filling enzyme DNA polymerase, which was found to show $32 \%$ and $54 \%$ decrease in pol $\gamma$ expression in GB and $A \beta(25-35)$, respectively, as compared to the control SH-SY5Y cells. The treatment of GB+A $\beta(25-35)$ showed 2.7 folds increase in the expression of pol $\gamma$ as compared to A $\beta(25-35)$ treatment alone in SH-SY5Y cells studied after $24 \mathrm{hr}$ time period (Fig.-4d). Based on previously reported studies, the expression of the nuclear polymerase, pol $\beta$ was found to be reduced in $\mathrm{AD}$ brain tissues as compared to healthy controls. ${ }^{38,39}$ However, the pre-treatment of GB followed by oxidative stress induction by $\mathrm{A} \beta(25-35)$ caused an increase in pol $\gamma$ expression. The activity of mitochondrial polymerase was found to be reduced in $\mathrm{AD}$ brain samples as reported by another study. ${ }^{42}$ These results suggest that GB possesses potential to stimulates the impaired BER pathway, due to $\mathrm{A} \beta$ stress, in the mitochondria.

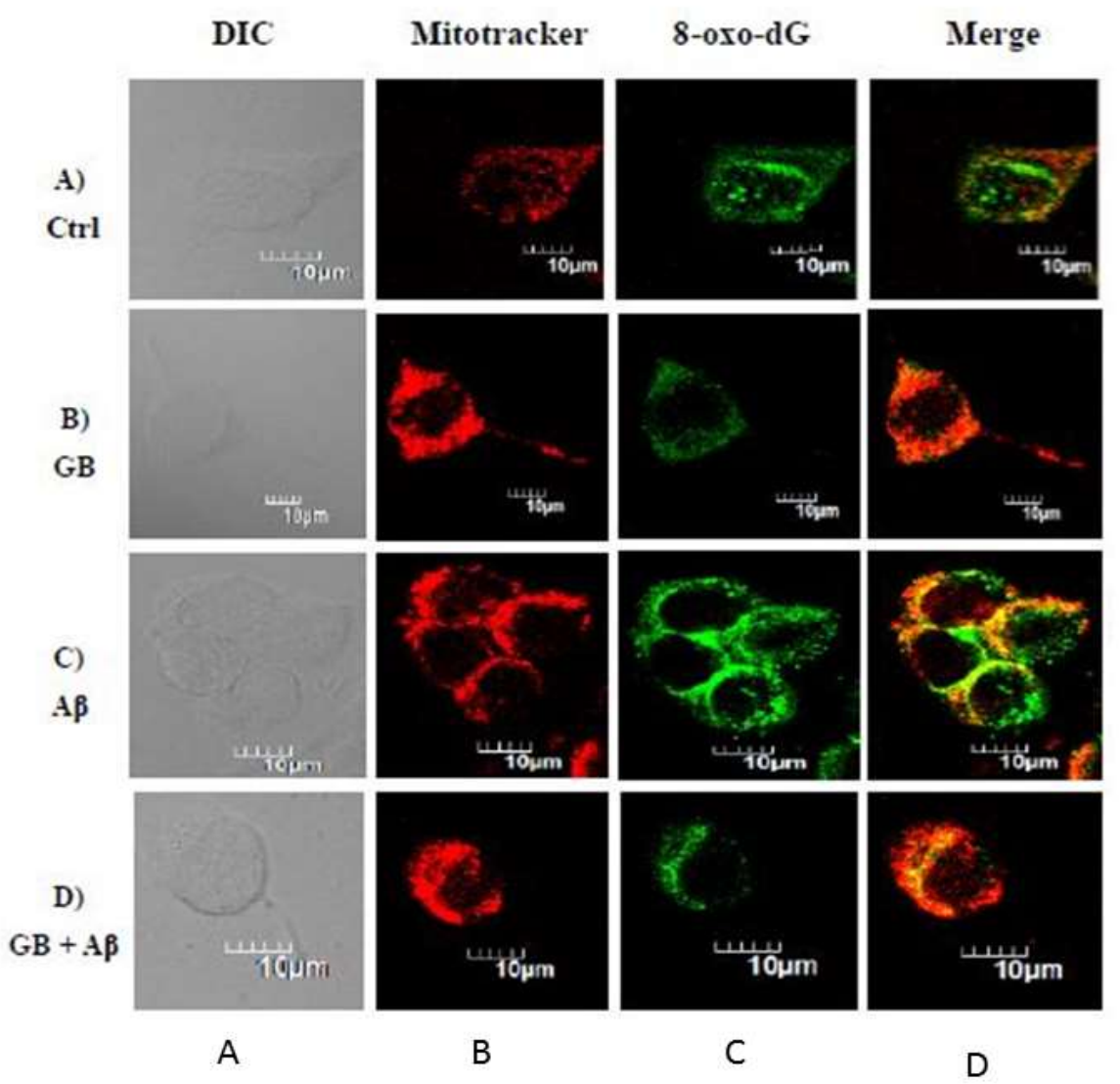

Fig.-3: Estimation of DNA damage by 8-oxo-dG sites in the mitochondria against $A \beta(25-35)$-induced oxidative stress and GB treatment by immunofluorescence using Olympus confocal laser scanning microscope. Mitochondria were stained with mitotracker. The first vertical panel shows DIC images of the SH-SY5Y cells; the second panel shows cells stained with mitotracker; the third panel shows DNA damage (8-oxo-dG) sites; and the fourth panel shows merged images of mitochondria and 8-oxo-dG sites in SH-SY5Y cells. Horizontal panels 1, 2, 3, \& 4 show treatment with $\mathrm{GB}, \mathrm{A} \beta(25-35)$, and $\mathrm{GB}+\mathrm{A} \beta(25-35)$, respectively. The scale bar used in these images is $10 \mu \mathrm{m}$.

Expression and Subcellular Distribution Analysis of the Multifunctional Enzyme: APE1

Further, the effect of $A \beta(25-35)$-mediated oxidative stress on the transcriptional regulation in terms of mRNA expression of APE1, a major BER-pathway enzyme and a key regulator of various transcription factors was determined by Reverse-Transcriptase PCR in this study. Significant attenuation (29\%) in the expression of APE1 was observed when the SH-SY5Y cells were treated with A $\beta(25-35)$ when compared with the untreated control cells after $24 \mathrm{hr}$ of the treatment time period. On the other hand, pre-incubating the SH-SY5Y cells with GB prior to the administration of $A \beta(25-35)$ increased the mRNA expression of APE1 by a significant level (63\%), as compared to the A $\beta(25-35)$-treated SH-SY5Y cells (Fig.-5a) 
RASĀYAN J. Chem.

Vol. 13 | No. 1 |306 - 321| January - March | 2020

pointing towards the modulation of APE1 expression at the transcriptional level upon pre-treatment with GB under the $A \beta$-induced oxidative stress conditions.

In addition, the effect of $A \beta(25-35)$-induced oxidative stress on translational regulation in terms of protein expression and subcellular distribution of APE1 was studied. In the mitochondria it was found that the treatment of GB showed marginal increase in the APE1 expression as compared to untreated control SHSY5Y cells, while $A \beta(25-35)$ resulted in increased immunoreactivity and foci formation; and further with the pre-treatment of GB against $A \beta(25-35)$ treatment caused decreased expression and foci formation of APE1 (Fig.-4e).

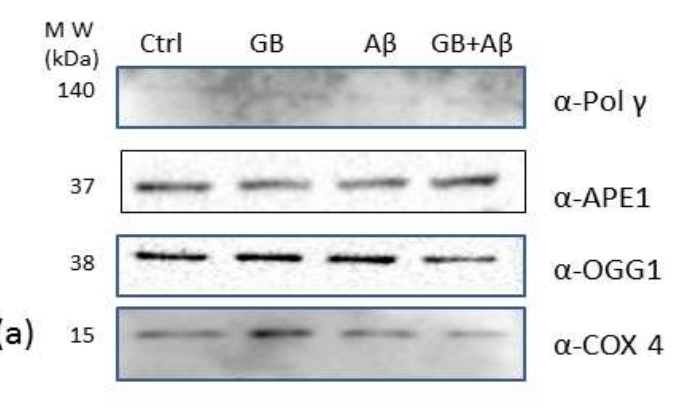

(d)

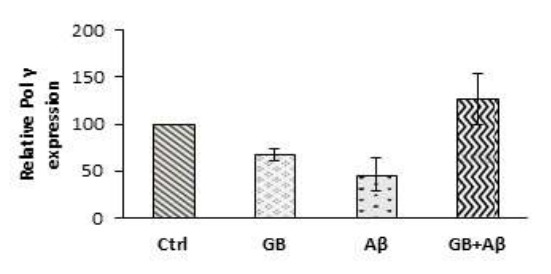

(b)

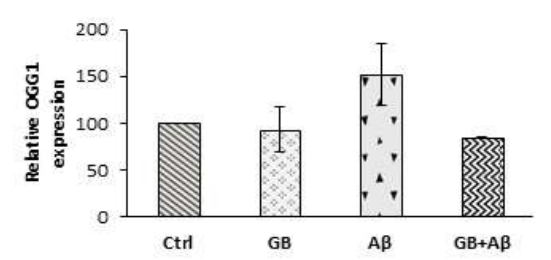

(c)
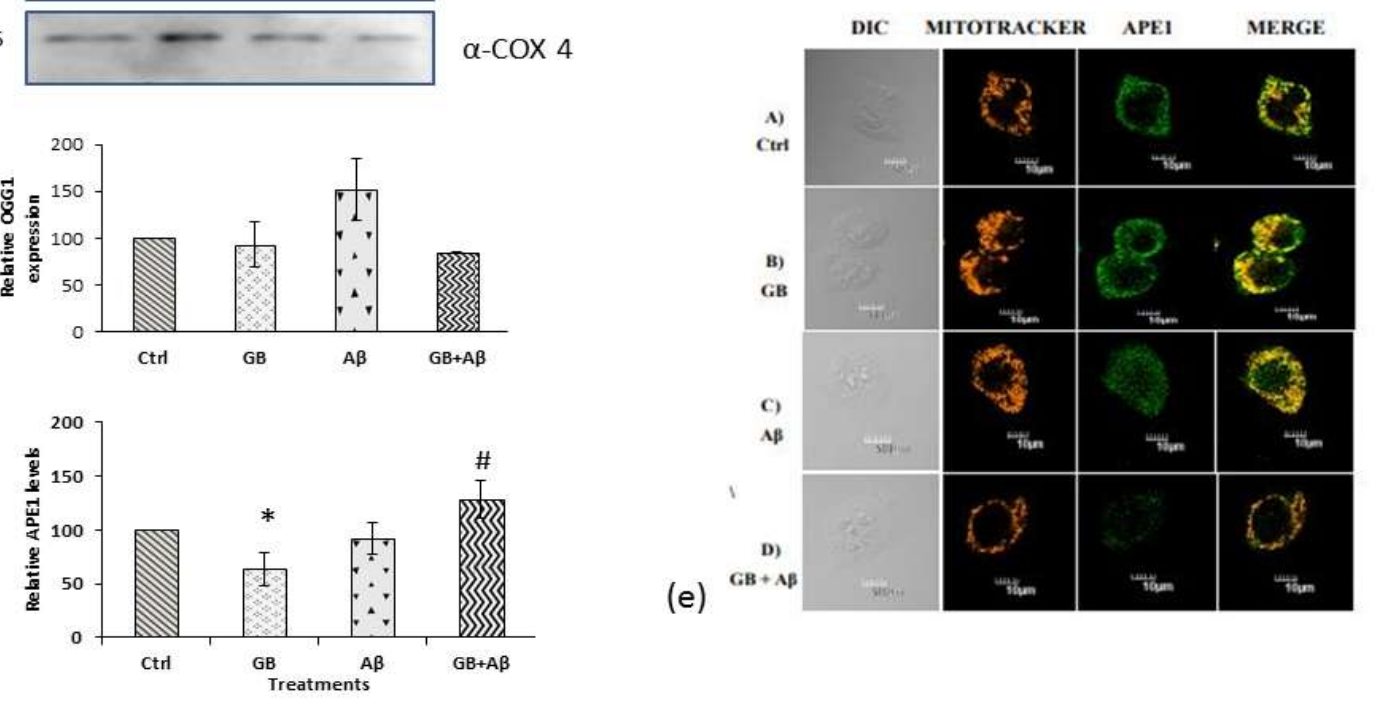

Fig.-4: Mitochondrial expression of BER pathway enzymes. (a) Representative images of bands of protein expression of BER pathway enzymes. Densitometric analysis of (b) OGG1, (c) APE1, and (d) Polymerase gamma

$(\gamma)$ relative to the untreated control, in mitochondrial lysates (normalized with COX-4 as a loading control) in

different treatments. The results are presented as mean \pm standard error $(n=2)$. For $(c)$ results are presented as mean $\pm \mathrm{SD}(\mathrm{n}=3)$ and student's t-test was performed and the data was considered statistically significant at ${ }^{*} \mathrm{p} \leq 0.05$ when GB, $A \beta(25-35)$ and GB $+\mathrm{A} \beta(25-35)$ treated SH-SY5Y cells were compared with control and ${ }^{\#} \mathrm{p} \leq 0.05$ when

$\mathrm{GB}+\mathrm{A} \beta(25-35)$ treated SH-SY5Y cells were compared with A $\beta(25-35)$ treated SH-SY5Y cells. (e) Confocal images representing red (mitotracker), green (APE1 expression), and merged APE1 expression in the mitochondria.

Western blot analysis in the total cell lysates documented significant upregulation of APE1 expression in $\mathrm{GB}+\mathrm{A} \beta(25-35)$ treated SH-SY5Y cells as compared to the A $\beta(25-35)$ treated SH-SY5Y cells after $24 \mathrm{hr}$ of the treatment period (Fig.-5b). The nuclear localization of APE1 up on A $\beta(25-35)$-induced oxidative stress was also found to be increased as compared to the untreated control SH-SY5Y cells (Fig.-5c).

This advocates that APE1 might be challenged during the onset of progressive neurodegenerative disorder AD. The phosphorylation of APE1 at Thr232 position by Cdk5 was found to make neurons more sensitive to death via increased DNA damage by reducing its endonuclease activity. Overexpression of wild-type APE1 and APE ${ }^{232 \mathrm{~A}}$ resulted in the protection of neurons against MPTP (1-methyl-4-phenyl1,2,3,6-tetrahydropyridine). Further in the study, increased phosphorylation of APE1 was found in AD and PD post mortem brain samples; thus ascertaining the important role of APE1 in AD and PD. ${ }^{43}$ In 
RASĀYAN J. Chem.

Vol. 13 | No. 1 |306 - 321| January - March | 2020

addition to its repair function, APE1 under $A \beta$ stress may be participating in regulating other redox signaling mechanisms as discussed earlier. ${ }^{13-17,39,44}$ On the other hand, pre-treatment of the antioxidant GB showed further increase in both transcriptional as well as translational expression of APE1, strengthening GB's role as a neuroprotective agent via increasing the expression of APE1, an emerging neuroprotective enzyme. ${ }^{3,11,18,19,45}$ Our previous study, showed that ectopic expression of APE1 along with GB pretreatment displayed restoration of activities of mitochondrial electron transport chain complexes (OXPHOS) against A $\beta(25-35)$ treatment in SH-SY5Y cells. ${ }^{3}$ According to one study, APE1 overexpression protected the cultured neurons from the radiation-induced cell death too. ${ }^{45}$

(a)

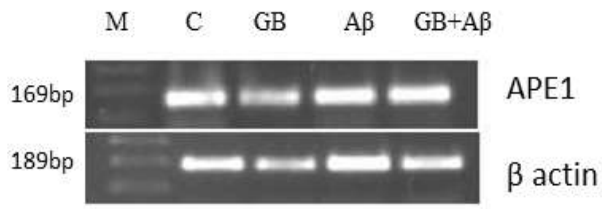

(b)

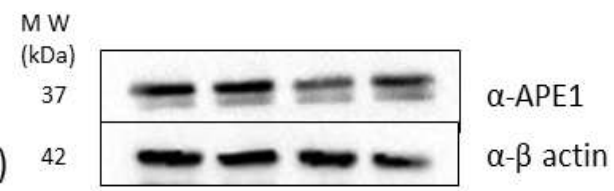

(c)

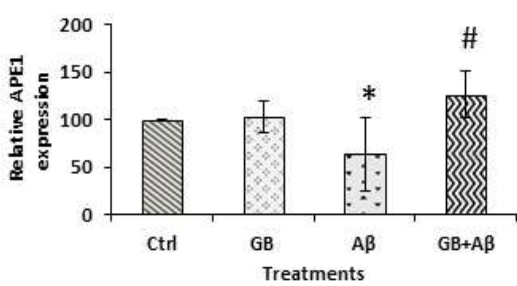

DIC
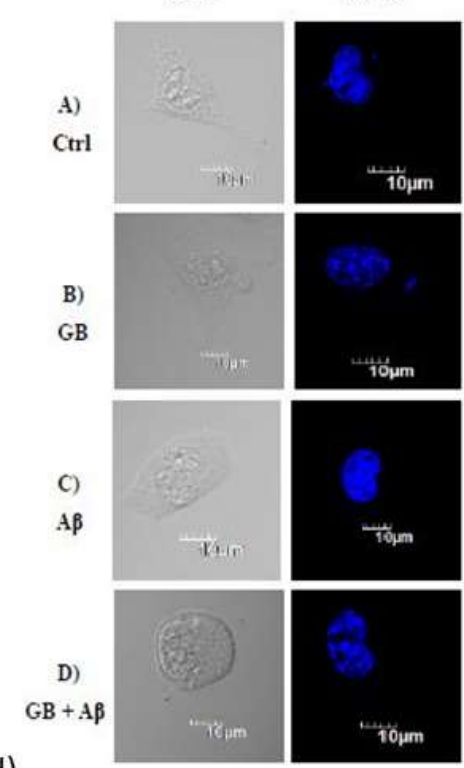
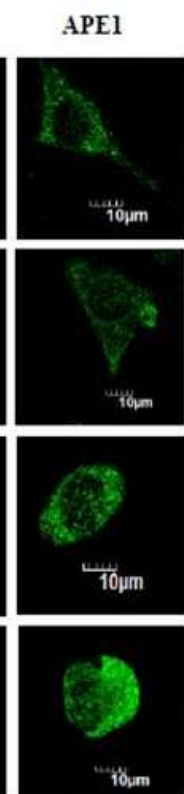

MERGE
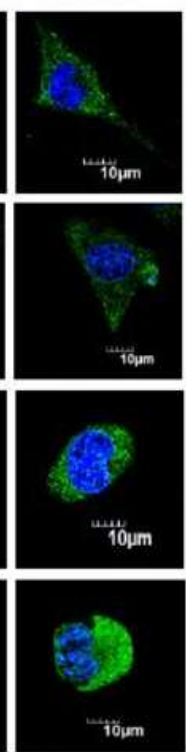

(d)

Fig.-5: Expression of APE1: (a) mRNA expression of APE1 in different treatments. (b) Image of Protein expression of APE1 in whole-cell lysates. (c) Densitometric analysis of APE1 protein expression normalized with $\beta$ actin in different treatments. The results are presented as mean $\pm \mathrm{SD}(\mathrm{n}=3)$. The data were considered statistically significant at ${ }^{*} \mathrm{p} \leq 0.05$ when GB, A $\beta(25-35)$ and GB $+\mathrm{A} \beta(25-35)$ treated SH-SY5Y cells were compared with the untreated control, and ${ }^{\#} \mathrm{p} \leq 0.05$, when $\mathrm{GB}+\mathrm{A} \beta(25-35)$ treated SH-SY5Y cells were compared with A $\beta(25-35)$, treated SHSY5Y cells. (d) Confocal images of SH-SY5Y cells treated in four groups, DAPI (blue) represents nucleus, APE1 expression is represented by (green) alexa-flour 488 and merged image represents APE1 expression and DAPI stain.

\section{GB Restores Mitochondrial Membrane Potential (MMP) Against A $\beta(25-35)$ Disruption}

The mitochondrial membrane potential was analyzed in different treatment groups as stated above and it was found that $10 \mu \mathrm{M}$ treatment of $A \beta(25-35)$ for $24 \mathrm{hr}$ showed a significant decrease of $43 \%$ in mitochondrial membrane potential (red/green ratio) as compared to the control untreated SH-SY5Y cells. Whereas, the pre-treatment of $10 \mu \mathrm{M}$ GB for $3 \mathrm{hr}$ and followed by oxidative stress induction by $10 \mu \mathrm{M}$ $\mathrm{A} \beta(25-35)$ showed significant increase in mitochondrial membrane potential by 1.8 folds as compared to $\mathrm{A} \beta(25-35)$ treatment, therefore restoring the mitochondrial membrane potential to the basal level as comparable to the untreated control SH-SY5Y cells (Fig.6), thus pointing towards the role of A $\beta$ in inducing oxidative stress, possibly through disruption of mitochondrial functions. According to a recent study, it was found that $\mathrm{H}_{2} \mathrm{O}_{2}$ caused a decrease in mitochondrial membrane potential in SH-SY5Y cells as revealed by the red/green fluorescence ratio of JC-1 dye. ${ }^{46}$ In another study, melatonin restored mitochondrial membrane potential in $\mathrm{AD}$ cell model. ${ }^{47}$ 
RASĀYAN J. Chem.

Vol. 13 | No. 1 |306 - 321| January - March | 2020

GB Inhibits Apoptosis Induced by A $\beta(25-35)$

Furthermore, the disruption of mitochondrial membrane potential leads to the initiation of the apoptotic pathway (caspase dependent) by the release of cytochrome $\mathrm{c}$ through the opening of mitochondrial permeability transition pores (MPTPs). Therefore, the active caspase 9 (p35) and AIF (57kDa) expression were evaluated in the whole-cell lysates of different treatment groups of SH-SY5Y cells by Western blot analysis. The expression of both AIF and caspase 9 was found to be increased by $9 \%$ and $19 \%$, respectively, in $\mathrm{A} \beta(25-35)$ treated SH-SY $5 Y$ cells; decrease by $25 \%$ and no change, respectively, in GB only treated SH-SY-5Y cells; and further in GB+A $\beta(25-35)$ treated SH-SY5Y cells decrease by $24 \%$ and $45 \%$, respectively, was observed as compared to A $\beta(25-35)$ treated SH-SY5Y cells after $24 \mathrm{hr}$ of treatment time point.
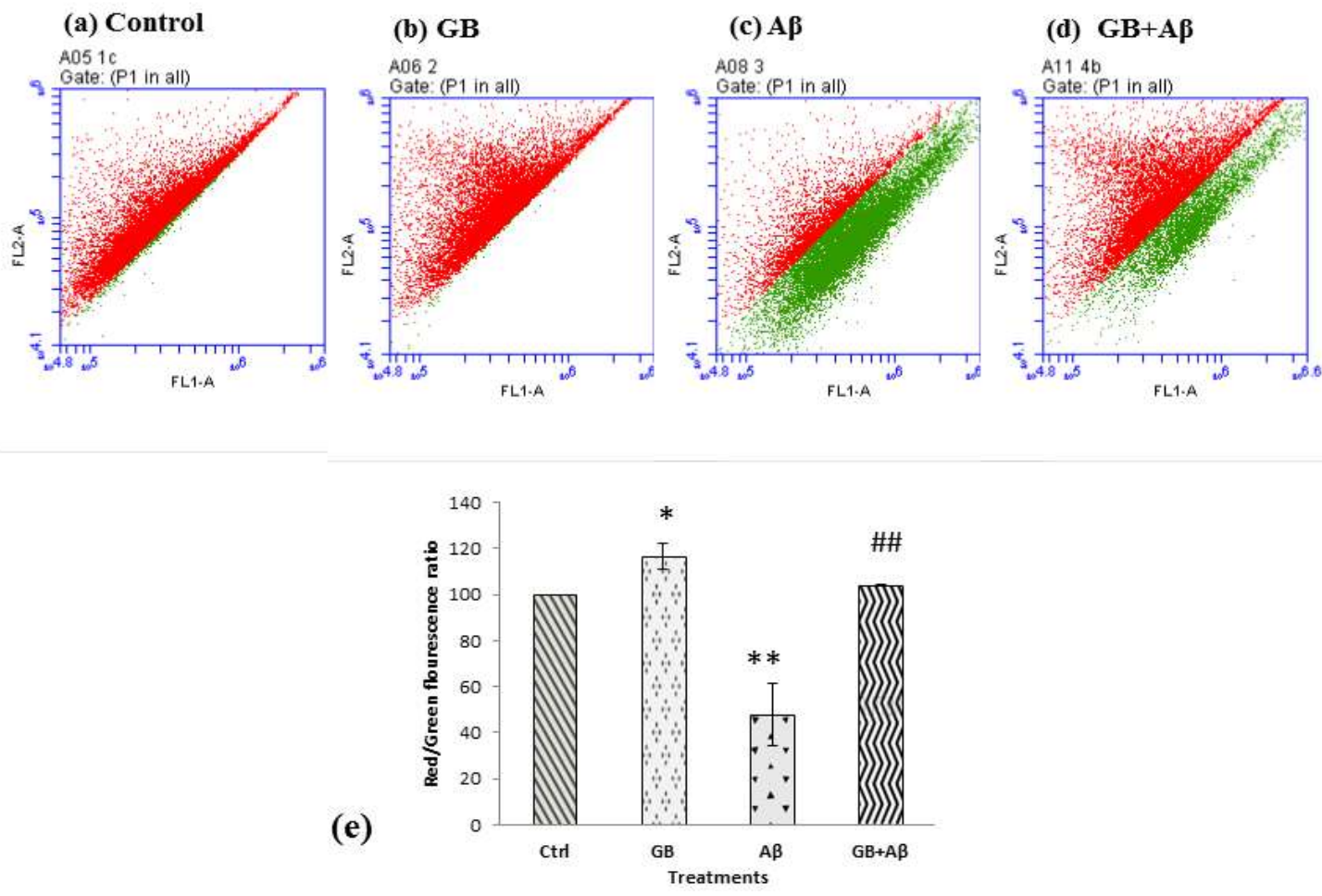

Fig.-6: Mitochondrial membrane potential determination by JC1. Dot plots showing the change in mitochondrial membrane potential in SH-SY5Y cells. (a) Control, (b) GB, (c) A $\beta(25-35)$, and (d) GB+A $\beta(25-35$ ) treatment groups. (e) Graph representing \% change in the ratio of red/green in different treatment groups. The results are presented as mean \pm SD $(n=3)$. The data was considered statistically significant at ${ }^{*} \mathrm{p} \leq 0.05$ and ${ }^{* *} \mathrm{p} \leq 0.005$ when GB, $A \beta(25-35)$ and GB $+\mathrm{A} \beta(25-35)$ treated SH-SY5Y cells were compared with the untreated control SH-SY5Y cells and ${ }^{\#} \mathrm{p} \leq 0.005$ when GB $+\mathrm{A} \beta(25-35)$ treated SH-SY5Y cells were compared with A $\beta(25-35)$ treated SH-SY5Y cells.

Studies have pointed out the increase in caspase 9 activity upon treatment of A $\beta(25-35)$ in SH-SY5Y cells as compared to the untreated control cells ${ }^{48}$, and $A \beta$-mediated stimulation in the protein expression of active caspase 9 in rat hippocampus. ${ }^{49}$ The expression of AIF (E1) a marker of late apoptosis found to be increased marginally under $A \beta(25-35)$ stress. The expression of both active caspase 9 and AIF decreased upon pre-treatment of GB followed by $\mathrm{A} \beta(25-35)$ stress in SH-SY5Y cells, thus advocating the neuroprotective role of GB. In line with this earlier, it was reported that $A \beta$ was found to be disrupting the mitochondrial biogenesis and hence its function, which further leads to the opening of MPTPs and initiation of apoptosis. ${ }^{5,20}$ In an another study, translocation of AIF to the nucleus was observed during the early stages of $\mathrm{AD}$ in $\mathrm{CA} 1$ neurons and at late stages in $\mathrm{CA} 2$ neurons as compared to the age-matched controls. $^{50}$

Taken together, through this study and available literature, we can ascertain that the diterpenoid phytochemical GB renders neuroprotection through maintenance of mitochondrial integrity by decreasing 
RASĀYAN J. Chem.

Vol. 13 | No. 1 |306 - 321| January - March | 2020

ROS/RNS, possibly by protecting the functions of antioxidant enzymes (SOD and Catalase); by reducing oxidative DNA base damage (8-oxo-dG) via its ability to reduce the oxidative free radical generation and by modulating the expression and functions of the mitochondrial BER-pathway enzymes; via restoring the mitochondrial membrane potential and thus inhibiting apoptosis against A $\beta$-induced oxidative stress in cultured human neuroblastoma SH-SY5Y cells, a well-accepted AD model.

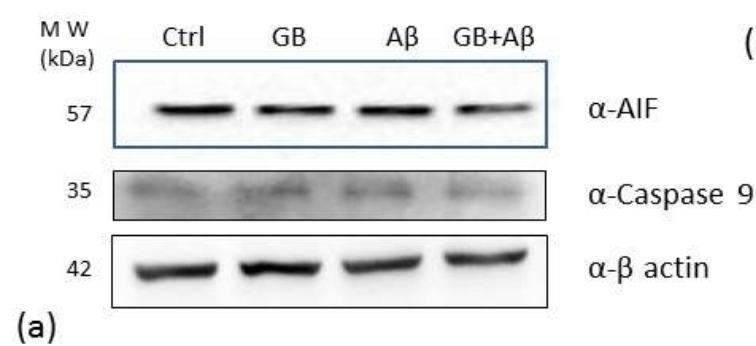

(b)
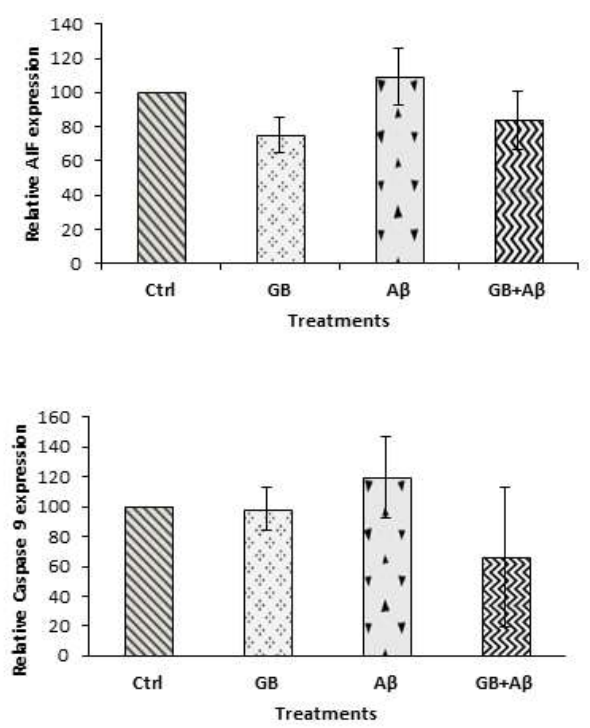

(c)

Fig.-7: Protein expression of AIF and caspase 9. (a) Representative images corresponding bands of Western blot of AIF, caspase 9 and $\beta$-actin. (b) \& (c) are the graphical representations of densitometric analysis of relative AIF and caspase 9 expressions (normalized with $\beta$-actin), respectively, in whole-cell lysates of SH-SY5Y cells in treatment groups. The results are presented as mean \pm standard error $(n=2)$.

\section{CONCLUSION}

The present study evaluated the altered cellular responses induced by A $\beta(25-35)$ in SH-SY5Y cells and the role of antioxidant GB in counteracting oxidative stress. $A \beta(25-35)$ contributes to exacerbating the oxidative stress by an imbalance of ROS/RNS, disrupting cellular biomolecules (enzymes and DNA) and antioxidant defense system, repair capacity of cells and mitochondrial functions. Through this study, we demonstrate the protection of SH-SY5Y cells by GB's pre-treatment followed by A $\beta(25-35)$ stress induction through rescuing the altered cellular responses and restoring the mitochondrial functions. This study also points out the importance of antioxidant phytochemicals like GB in managing the neurodegenerative diseases like $\mathrm{AD}$, where oxidative stress plays a major role in the pathology of the disease. Further studies are required to determine other important parameters of AD pathology, which can be modulated by the use of GB a natural antioxidant, for managing and delaying the onset and progression of $\mathrm{AD}$.

\section{ACKNOWLEDGMENT}

Funding for this research was provided to A.K.M. by the grant received from the Department of Science and Technology (SR/CSI/288/2012/G), New Delhi, India. N.K. acknowledges financial support in the form of Junior Research Fellowship (JRF) from the Indian Council of Medical Research (ICMR), New Delhi, India. S.K. thankfully acknowledges Junior Research Fellowship (JRF) from the University Grants Commission (CSIR-UGC-JRF), Govt. of India. Central Instrumentation Laboratory (CIL) facility of CUPB is thankfully acknowledged for providing a confocal microscopy facility. Because of the limited focus of the article, many relevant and appropriate references could not be included, for which the authors apologize.

\section{REFERENCES}

1. C. Haas and D.J. Selkoe, Cell, 75, 1039(1993), DOI: 10.1016/0092-8674(93)90312-E 
2. A. Aronis, J.A. Melendez, O. Golan, S. Shilo, N. Dicter and O. Tirosh, Cell Death and Differentiation, 10(3), 335(2003), DOI:10.1038/sj.cdd.4401150

3. N. Kaur, M. Dhiman, J.R. Perez-Polo, and A.K. Mantha, Journal of Neuroscience Research, 93(6), 938(2015), DOI: 10.1002/jnr.23565

4. X. Wang, B. Su. H. Fujioka and X. Zhu, American Journal of Pathology, 173(2), 470(2008), DOI:10.2353/ajpath.2008.071208

5. J. Hroudova, N. Singh and Z. Fisar, BioMed Research International, 2014, 1(2014), DOI: $10.1155 / 2014 / 175062$

6. R.W. Omar, Y.J. Chyan, A.C. Andorn, B. Poeggeler, N.K. Robakis and M.A. Poppolla, Journal of Alzheimer's Disease, 1(3), 139(1999), DOI: 10.3233/JAD-171145

7. E.J. Yoon, H.J. Park, G.Y. Kim, H.M. Cho, J.H. Choi, H.Y. Park, J.Y. Jang, H. Rhim, S. M. Kang, Experimental \& Molecular Medicine, 41, 611(2009), DOI: 10.3858/emm.2009.41.9.067

8. E.H. Gray, K.J. De Vos, C. Dingwall, M.S. Perkinton and C.C. Miller, Journal of Alzheimers Disease, 21, 1101(2010), DOI: 10.3233/JAD-2010-100717

9. A.J. Podlutsky, I.I. Dianova, V.N. Podust, V.N. Bohr and G.L. Dianov, The EMBO Journal, 20(6), 1477(2001), DOI: $10.1093 / \mathrm{emboj} / 20.6 .1477$

10. A. Sliwinska, D. Kwiatkowski, P. Czarny, M. Toma, P. Wigner, J. Drzewoski, K. Fabianowska-Majewska, J. Szemraj, M. Maes, P. Galecki and T. Sliwinski, Journal of Neurological Sciences, 368, 155(2016), DOI:10.1016/j.jns.2016.07.008

11. I. Gill, S. Kaur, N. Kaur, M. Dhiman and A.K. Mantha, Journal of Alzheimer's Disease, 60(s1), S25(2017), DOI: 10.3233/JAD-161086

12. N. Kaur, B. Sarkar, S. Mittal, M. Dhiman, G. Taglialatela, R.J. Perez-Polo and A.K. Mantha, Free Radicals in Human Health and Disease, pp 175-207(2015), Springer, India, DOI: 10.1007/978-81-3222035-0_13

13. S. Thakur, B. Sarkar, R.P. Cholia, N. Gautam, M. Dhiman and A.K. Mantha, Experimental \& Molecular Medicine, 46(7), e106(2014), DOI: 10.1038/emm.2014.42

14. A.K. Mantha, B. Sarkar and G. Tell, Mitochondrion, 16, 38(2014), DOI:10.1016/j.mito.2013.10.007

15. M.R. Kelley, M.M. Georgiadis and M.L. Fishel. Current Molecular Pharmacology, 5(1), 36(2012), DOI: $10.2174 / 1874467211205010036$

16. G. Tell, F. Quadrifoglio, C. Tiribelli and M.R. Kelley, Antioxidants \& Redox Signaling, 11(3),601(2009), DOI: $10.1089 /$ ars.2008.2194

17. K.K. Bhakat, A.K. Mantha and S. Mitra, Antioxidants \& Redox Signaling, 11(3), 621(2009), DOI: $10.1089 /$ ars.2008.2198

18. A.K. Mantha, M. Dhiman, G. Taglialatela, R.J. Perez-Polo and S. Mitra, Journal of Neuroscience Research, 90, 1230(2012), DOI:10.1002/jnr.23018

19. B. Sarkar, M. Dhiman, S. Mittal and A.K. Mantha, Metabolic Brain Disease, 32(6), 2045(2017), DOI: $10.1007 / \mathrm{s} 11011-017-0093-2$

20. M. Hashimoto, E. Rockenstein, L. Crews and E. Masliah, NeuroMolecular Medicine, 4(1-2), 21(2003), DOI: $10.1385 / \mathrm{NMM}: 4: 1-2: 21$

21. S.A. Susin, H.K. Lorenzo,N. Zamzami, I. Marzo, B. E. Snow, G.M. Brothers, J. Mangion, E. Jacotot, P. Costantini, M. Loeffler, N. Larochette, D.R. Goodlett, R. Aebersold, D.P. Siderovski, J.M. Penninger, G. Kroemer, Nature, 397,441(1999), DOI:10.1038/17135

22. H. Otera, S. Ohsakaya, Z. Nagaura, N. Ishihara and K. Mihara, EMBO Journal, 24,1375(2005), DOI: 10.1038/sj.emboj.7600614

23. G.M. Cragg, D.J. Newman and D.G. Kingston, Comprehensive Natural Products II: Chemistry and Biology, 2, 5(2010), DOI: 10.1016/B978-008045382-8.00033-2

24. J. Srivastava, D. Deepak and P. Prakash, Rasayan Journal of Chemistry, 8, 161(2015)

25. J. A. Olugbuyiro, A. S. Banwo, A. O. Adeyemi, O. S. Taiwo and O. A. Akintokun, Rasayan Journal of Chemistry, 11, 798(2018), DOI: 10.31788/RJC.2018.1121823

26. H.S. Chang, H.C. Huang, T.C. Huang, P.C. Yang and Y.C. Wang, Bio-protocol, 3, (2013), DOI: 10.21769/BioProtoc. 431

27. Y.J. Xie and W.B. Shen. In Plant Salt Tolerance, pp. 191-200(2012), Humana Press, Totowa, NJ, DOI: 10.1007/978-1-61779-986-0_12 
28. R.P. Soultanakis, R.J. Melamede, I.A. Bespalov. S.S. Wallace, K. B. Beckman, B. N. Ames, D. J. Taatjes and Y M. Janssen-Heininger, Free Radical Biology and Medicine, 28, 987(2000), DOI: 10.1016/s08915849(00)00185-4

29. V. Rhein, M. Giese, G. Baysang, F. Meier, S. Rao, K.L. Schulz, M. Hamburger and A. Eckert, PloS one, 5(8), e12359(2010), DOI: 10.1371/journal.pone.0012359

30. R.P. Cholia, S. Kumari, S. Kumar, M. Kaur, M. Kaur, R. Kumar, M. Dhiman and A.K. Mantha, Metabolic Brain Disease, 32(5), 1705(2017), DOI: 10.1007/s11011-017-0057-6

31. C.J. Weydert and J.J. Cullen, Nature Protocols, 5(1), 51(2010), DOI: 10.1038/nprot.2009.197

32. A. Perelman, C. Wachtel, M. Cohen, S. Haupt, H. Shapiro and A. Tzur, Cell Death \& Disease, 3(11), e430(2012), DOI: $10.1038 /$ cddis.2012.171

33. C.J. Pike, D. Burdick, A.J. Walencewicz, C.G. Glabe and C.W. Cotman, The Journal of Neuroscience, 13(4), 1676(1993), DOI:10.1523/JNEUROSCI.13-04-01676.1993

34. J. Krieglstein, F. Ausmeier, H. El-Abhar, K. Lippert, M. Welsch, K. Rupalla and P. Henrich-Noack, European Journal of Pharmaceutical Sciences, 3, 39(1995), DOI:10.1007/s00018-003-3080-1

35. X. Yang, T. Zheng, H. Hong, N. Cai, X. Zhou, C. Sun, L. Wu, S. Liu, Y. Zhao, F. Jin and M. Fan, Frontiers of Medicine, 12(3), 307(2018), DOI:10.1007/s11684-017-0547-2.

36. Y. Hou, S. Lautrup, S. Cordonnier, Y. Wang, D L. Croteau, E. Zavala, Y. Zhang, K. Moritoh, J.F. O'Connel, B.A. Baptiste, T.V. Stevnsner, M.P. Mattson and V.A. Bohr, Proceedings of National Academy of Sciences, 115(8), E1876(2018), DOI: 10.1073/pnas.1718819115

37. X. Ba, L. Aguilera-Aguirre, Q. Rashid, A. Bacsi, Z. Radak, S. Sur and I. Boldogh, International Journal of Molecular Sciences 15(9), 16975(2014), DOI: 10.3390/ijms150916975

38. L. Weissman, D. G. Jo, M.M. Sørensen, N.C. de Souza-Pinto, W.R. Markesbery, M.P. Mattson and V.A. Bohr, Nucleic Acids Research, 35(16), 5545(2007), DOI: 10.1093/nar/gkm605

39. M.S. Lillenes, M. Støen, M. Gómez-Muñoz, R. Torp, C.C. Günther, L.N. Nilsson and T.Tønjum, Mechanisms of Ageing and Development, 134(10), 467(2013), DOI: 10.1016/j.mad.2013.09.002

40. T. Saitoh, K. Shinmura, S. Yamaguchi, M. Tani, S. Seki, H. Murakami, Y. Nojima and J. Yokota, Mutational Research. 486, 31(2001), DOI:10.1016/s0921-8777(01)00078-7

41. J.W. Hill, T.K. Hazra, T. Izumi and S. Mitra, Nucleic Acids Research, 29, 430(2001), DOI: 10.1093/nar/29.2.430

42. C. Canugovi, R.A. Shamanna, D.L. Croteau and V.A. Bohr, Neurobiology of Aging, 35(6), 1293(2014), DOI: $10.1016 /$ j.neurobiolaging.2014.01.004

43. E. Huang, D. Qu, Y. Zhang, K. Venderova, M.E. Haque, M.W. Rousseaux and D.S. Park, Nature Cell Biology, 12(6), 563(2010), DOI: $10.1038 /$ ncb2058

44. M.L. Hegde, P.M. Hegde, K.S. Rao and S. Mitra, Journal of Alzheimer's Disease, 24(s2), 183(2011), DOI: $10.3233 / \mathrm{JAD}-2011-110281$

45. M.R. Vasko, C.Guo, E.L. Thompson and M.R. Kelley, DNA Repair, 10(9), 942(2011), DOI: 10.1016/j.dnarep.2011.06.004

46. X. Zhao, J. Fang, S. Li, U. Gaur, X. Xing, H. Wang and W. Zheng, International Journal of Molecular Sciences, 20(11), 2680(2019), DOI: 10.3390/ijms20112680

47. C. F. Wang, C.Y. Song, X. Wang, L.Y. Huang, M. Ding, H. Yang, P. Wang, L.L. Xu, Z.H. Xie and J.Z. Bi, European Review for Medical and Pharmacological Sciences, 23(8), 3542(2019), DOI: 10.26355/eurrev_201904_17723

48. M. Liu, X. Bai, S. Yu, W. Zhao, J. Qiao, Y. Liu and S. Wang, Molecules, 24(15), 2687(2019), DOI: 10.3390/molecules24152687

49. Y. Tian, K.Y. Chen, L.D. Liu, Y.X. Dong, P. Zhao and S.B. Guo, Mediators of Inflammation, 2018(2018), DOI: $10.1155 / 2018 / 3802324$

50. J.H. Lee, Y.H. Cheon, R.S. Woo, D.Y. Song, C. Moon and T.K. Baik, Anatomy \& Cell Biology, 45(1), 26(2012), DOI: $10.5115 / \mathrm{acb} .2012 .45 .1 .26$

[RJC-5596/2019] 